\title{
PENINGKATAN PRESTASI BELAJAR SISWA KELAS XI IPS 1 MAN 2 BANJARMASIN PADA MATERI AKHLAK TERPUJI MELALUI PENGGUNAAN POWER POINT
}

\author{
Khairunnisawati \\ Madrasah Aliyah Negeri 2 Banjarmasin \\ Email: khairunnisawati999@gmail.com \\ Website : https://jurnal.uin-antasari.ac.id/index.php/ptkpend/index \\ Received: Juni 2019; Accepted: Juli 2019; Published: Agustus 2019
}

\begin{abstract}
The purpose of this study was to find out increasing students' achievement of moral praised topic in adolescent association through the use of power point. This study used a class action research design with 2 cycles. Each cycle consists of planning, implementation, observation and evaluation, and analysis and reflection. The subjects in this study were students of class XI IPS 1 with a total of 38 students. Data collected using test techniques. Furthermore, it was analyzed by quantitative descriptive and qualitative analysis techniques. The results of the study show that the use of power points in the moral praised topic in adolescent association can improve student learning achievement.
\end{abstract}

Keyword : students' achievement; power point; moral praised

\begin{abstract}
ABSTRAK
Tujuan penelitian ini ialah untuk mengetahui peningkatan prestasi belajar materi akhlak terpuji dalam pergaulan remaja melalui penggunaan power point. Penelitian ini menggunakan rancangan penelitian tindakan kelas (PTK) dengan 2 siklus. Masing-masing siklus terdiri dari tahap perencanaan, pelaksanaan tindakan, observasi dan evaluasi, serta analisis dan refleksi. Subjek dalam penelitian ini adalah siswa kelas XI IPS 1 dengan jumlah siswa sebanyak 38 orang. Data yang dikumpulkan menggunakan teknik tes. Selanjutnya, dianalisis dengan teknik analisis deskriptif kuantitatif dan analisis kualitatif. Hasil penelitian menunjukkan bahwa penggunaan power point pada materi akhlak terpuji dalam pergaulan remaja dapat meningkatkan prestasi belajar siswa.
\end{abstract}

Kata kunci : prestasi belajar; power point; akhlak terpuji

\section{PENDAHULUAN}

Dalam proses interaksi belajar mengajar guru merupakan orang yang memberikan pelajaran dan siswa adalah orang yang menerima pelajaran. Dalam mentransfer pengetahuan kepada siswa diperlukan pengetahuan atau kecakapan/keterampilan sebagai guru. Tanpa itu semua tidak mungkin proses interaksi belajar mengajar dapat berjalan secara kondusif. Disinilah kompetensi dalam arti kemampuan mutlak diperlukan guru dalam melaksanakan tugasnya sebagai pendidik.

Guru harus peka dan tanggap terhadap perubahan-perubahan, pembaharuan serta ilmu pengetahuan dan

teknologi yang terus berkembang sejalan dengan tuntutan kebutuhan masyarakat dan perkembangan zaman. Guru diharuskan untuk senantiasa meningkatkan wawasan ilmu pengetahuan, meningkatkan kualitas pendidikannya sehingga apa yang diberikan 
kepada siswanya tidak terlalu ketinggalan dengan perkembangan kemajuan zaman.

Proses belajar mengajar merupakan suatu proses yang mengandung serangkaian perbuatan guru dan murid atas dasar hubungan timbal balik, yang berlangsung dalam situasi edukatif untuk mencapai tujuan tertentu. Interaksi atau hubungan timbal balik antara guru dan siswa itu merupakan syarat utama bagi berlangsungnya proses belajar mengajar. Interaksi dalam peristiwa belajar mengajar mempunyai arti yang lebih luas, tidak sekedar hubungan antara guru dengan siswa, tetapi berupa interaksi edukatif. Dalam hal ini bukan hanya menyampaikan pesan berupa materi pelajaran, melainkan penanaman sikap dan nilai pada diri siswa yang sedang belajar sehingga hasil yang didapatkan dari proses pembelajaran dapat optimal.

Berdasarkan penelitian yang dilakukan pada siswa kelas XI IPS 1 Madrasah Aliyah Negeri 2 Banjarmasin, dapat diketahui prestasi belajar siswanya tergolong rendah. Ini dapat dibuktikan dengan adanya hasil tes ulangan aqidah akhlak materi akhlak terpuji dalam pergaulan remaja. Dari 38 siswa terdapat 12 siswa atau $34,21 \%$ yang mendapatkan nilai di bawah kriteria ketuntasan minimal. Untuk mengatasi permasalahan diatas, diperlukan tindakan yang nyata dari guru untuk meningkatkan prestasi belajar dengan melakukan perubahan pada tindakan yang digunakan proses pembelajaran di kelas. Salah satu tindakan yang dapat dilakukan adalah menggunakan media pembelajaran.

$$
\text { Menurut Sutirman (2013); }
$$

Suryandari, dkk (2018) dengan tersedianya media pembelajaran guru dapat menciptakan berbagai situasi baru dalam kelas, sehingga tidak membosankan. Media pembelajaran dapat membantu guru dalam menciptakan berbagai situasi kelas, menentukan metode pembelajaran yang akan dipakai dalam situasi yang berlainan dan menciptakan iklim emosional yang sehat di antara siswasiswanya serta membantu guru untuk "membawa" bahan pembelajaran ke dalam kelas dengan mudah. Materi yang sifatnya abstrak dan asing dapat menjadi konkret dan mudah dimengerti oleh siswa dengan adanya penggunaan media. Oleh karenanya siswa akan banyak terlibat dalam pembelajaran dan ada kemungkinan daya serap mereka terhadap pembelajaran akan bertambah baik dan maju (Rolina, 2017).

Menurut Daryanto (2013), penggunaan media pembelajaran dalam pembelajaran dapat memberikan pengaruh terapi positif pada siswa. Mereka belajar bekerja sama membagi ide dan pikirannya, memperkuat satu sama lain menghormati kemampuan dan pandangan orang lain. Dina (2011) menambahkan bahwa pemakaian media dalam proses pembelajaran dapat membantu pengembangan kreativitas guru dan siswa. Guru dapat memikirkan berbagai cara untuk menyajikan pelajarannya dengan menggunakan media tersebut sehingga lebih menarik. Berbagai topik pelajaran tertentu hasilnya mungkin kurang memuaskan apabila tidak menggunakan media pembelajaran.

Guru dapat menggunakan media pembelajaran sebagai fasilitator untuk membantu siswa-siswanya mendapatkan berbagai kompetensi pengajaran. Buku teks dan papan tulis pada umumnya membatasi kegiatan latihan utama guru. Media pembelajaran dapat membantu mengoptimalkan cara, tidak hanya untuk berkomunikasi dan mengajar pada siswa, tetapi juga untuk menampilkan kesalahan dan kebenaran mereka melalui umpan balik dari video atau kaset. Dengan demikian, guru dan tutor dapat memperbaiki teknik pembelajaran dan memperbaiki metodologinya.

Ada beberapa keuntungan menggunakan media pembelajaran, yaitu: (Robinson, 2008)

(1) Guru dapat mengajar tanpa hadir di kelas

(2) Guru dapat mengajar topik yang sama kepada banyak anak dalam berlainan kelas.

(3) Guru dapat memberikan pelajaran secara individualisasi atau kelompok. 
(4) Murid dapat belajar dengan kemampuannya sendiri pada berbagai bagian topik utama yang menarik perhatian mereka atau yang mendorong mereka pada pemahaman topik utama.

(5) Memberikan kesempatan kepada murid untuk berinisiatif semaksimal mungkin.

(6) Murid dan gurunya belajar memakai media pembelajaran semaksimal mungkin.

(7) Bagi guru dan murid ada kesempatan untuk menciptakan media pembelajaran sendiri.

(8) Menyimpan pelajaran untuk digunakan kemudian

Salah satu media yang dapat digunakan oleh guru adalah power point mengingat perkembangan Information and Communication Technology (ICT) atau Teknologi Informasi dan Komunikasi (TIK) dalam beberapa dekade terakhir berjalan sangat cepat. Power point merupakan salah satu media penyajian yang berbasis multimedia (Saputra dan Zinnurrain, 2018). Banyak hal yang didapat dari penggunaan power point dalam menyampaikan materi pembelajaran karena mampu menampilan teks, gambar, suara, video, animasi dan sebagainya. Dalam presentasi tugas, siswa akan lebih mudah menyajikan dengan menggunakan power point (Srimaya, 2017). Mengingat begitu besar manfaat media pembelajaran power point, maka di era globalisasi seperti saat ini, guru harus mampu membuat dan mengoperasikan power point secara tepat sehingga pembelajaran akan lebih berkualitas, karena siswa lebih mudah memahami materi ajar dan lebih menarik yang mampu meningkatkan prestasi belajar siswa. Oleh karena itu fokus penelitian ini adalah untuk mengetahui peningkatan prestasi belajar siswa pada materi akhlak terpuji dalam pergaulan remaja setelah menggunakan media power point.

\section{METODE PENELITIAN}

Penelitian ini dilaksanakan dengan menggunakan rancangan penelitian tindakan kelas (classroom action research) untuk mengatasi adanya masalah di kelas XI IPS 1 MAN 2 Banjarmasin. Penelitian ini dilaksanakan dalam 2 siklus, setiap siklus dalam penelitian memiliki 4 tahapan kegiatan yaitu: (1) perencanaan, (2) pelaksanaan, (3) pengamatan, (4) refleksi (Arikunto, Suharjo dan Supandi, 2014).

Penelitian ini dilaksanakan pada bulan Januari 2019 di kelas XI IPS 1 MAN 2 Banjarmasin. Subjek penelitian siswa kelas XI IPS 1 MAN 2 Banjarmasin berjumlah 38 orang yang terdiri 20 orang perempuan dan 18 orang laki-laki. Objek dalam penelitian ini prestasi belajar mereka. Data mengenai prestasi belajar dikumpulkan melalui teknik tes berupa pemberian soal pada setiap akhir siklus.

Analisis prestasi belajar siswa bertujuan untuk mengetahui tingkat penguasan konsep siswa dalam proses pembelajaran di kelas. Sesuai dengan Ketuntasan Kriteria Minimum MAN 2 Banjarmasin, siswa yang memperoleh nilai lebih atau sama dengan 75 dinyatakan tuntas belajar. Keberhasilan siswa dalam menguasai materi akhlak terpuji dalam pergaulan remaja ditunjukkan dengan nilai rata-rata siswa secara keseluruhan $\geq 75$, daya serap $\geq 75 \%$ dan ketuntasan belajar $\geq$ $75 \%$. Untuk mendeskripsikan keberhasilan siswa dalam mengikuti proses pembelajaran dapat dilihat pada Tabel 1.

Tabel 1 Kategori prestasi belajar kognitif siswa

\begin{tabular}{cc}
\hline Nilai & Kategori \\
\hline $91-100$ & Sangat tinggi \\
\hline $81-90$ & Tinggi \\
\hline $75-80$ & Sedang \\
\hline $50-74$ & Rendah \\
\hline $0-49$ & Sangat Rendah \\
\hline
\end{tabular}

(Widayoko, 2014)

Berdasarkan kriteria yang telah dibuat, maka peneliti menentukan tingkat kriteria keberhasilan tindakan pada penelitian ini dilihat dari peningkatan prestasi belajar siswa secara keseluruhan. Pada setiap siklus dikatakan meningkat jika menunjukkan tingkat daya serap siswa secara keseluruhan mencapai $\geq 75 \%$ dengan 
nilai masing-masing setiap subjek penelitian memperoleh nilai paling rendah 75 dan ketuntasan $\geq 75 \%$.

\section{HASIL DAN PEMBAHASAN}

Hasil penelitian pada penelitian ini adalah prestasi belajar siswa. Peningkatan data prestasi belajar siswa dalam penelitian ini dilihat dari 3 aspek yaitu rata-rata nilai prestasi belajar, daya serap dan ketuntasan belajar. Berikut peningkatan rata-rata nilai prestasi belajar siswa pada siklus II jika dibandingan dengan siklus I dapat dilihat pada Gambar 1.

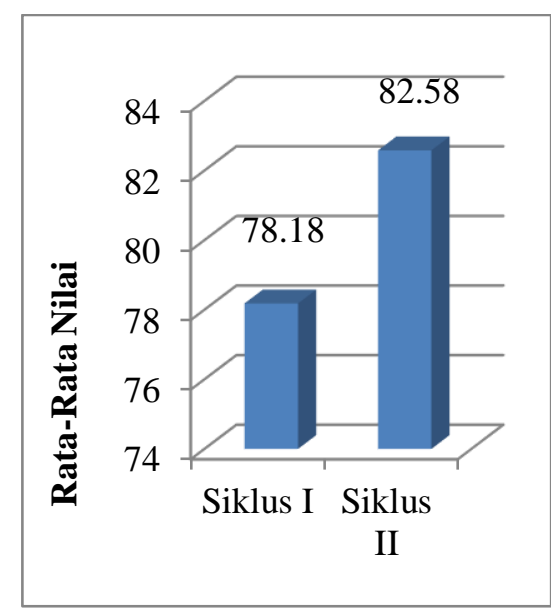

\section{Gambar 1 Peningkatan nilai rata-rata prestasi belajar pada setiap siklus.}

Kemudian, untuk peningkatan daya serap dan ketuntasan belajar pada siklus II jika dibandingkan dengan siklus I yang dapat dilihat pada pada Gambar 2.

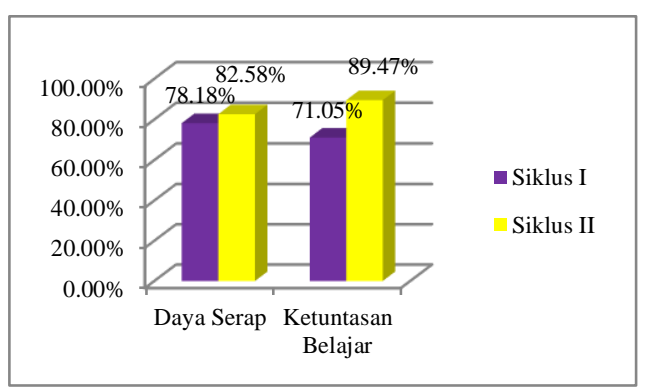

\section{Gambar 2 Peningkatan daya serap dan} ketuntasan belajar pada setiap siklus.

Penelitian ini merupakan upaya membantu siswa meningkatkan prestasi belajar siswa pada materi akhlak terpuji dalam pergaulan remaja dengan melaksanakan pembelajaran dengan menggunakan media power point. Untuk merealisasikan usaha tersebut, penelitian dilakukan melalui dua siklus yang terdiri dari empat komponen, yaitu: perencanaan tindakan, pelaksanaan tindakan, observasi, dan refleksi. Setiap pelaksanaan tindakan peneliti melakukan berbagai langkah sesuai dengan rencana perbaikan pembelajaran. Berikut pembahasan dari setiap pelaksanaan tindakan masing-masing siklus.

Berdasarkan hasil tes yang dilakukan di siklus I, diperoleh data yaitu nilai rata-rata prestasi belajar dari 38 siswa adalah sebesar 78,18 dan daya serap sebesar $78,18 \%$. Kemudian, jumlah siswa yang mendapatkan nilai diatas dan sama dengan nilai KKM (kriteria ketuntasan minimal) sebanyak 27 siswa atau 71,05\%. Sedangkan yang mendapatkan nilai di bawah nilai KKM sebanyak 11 siswa atau 28,95\%. Jika dibandingkan dengan kriteria minimal pembelajaran yang telah ditetapkan, maka hasil penelitian pada pembelajaran siklus I belum memenuhi kriteria minimal yang ditetapkan, yaitu ketuntasan belajar belum mencapai lebih dari atau sama dengan $75 \%$, maka berarti pembelajaran pada siklus I belum optimal dan dilanjutkan ke siklus berikutnya yaitu siklus II.

Pada tindakan di siklus II, guru berupaya lebih mengaktifikan siswa dalam proses pembelajaran agar prestasi belajar siswa lebih meningkat. Pada siklus II ini diketahui bahwa nilai rata-rata prestasi belajar dari 38 siswa adalah sebesar 82,58 dengan daya serap sebesar $82,58 \%$. Jumlah siswa yang mendapatkan nilai KKM (kriteria ketuntasan minimal) sebanyak 34 siswa atau $89,47 \%$. Sedangkan yang mendapatkan nilai di bawah nilai KKM sebanyak 4 siswa atau 10,53\%.

Berdasarkan nilai rata-rata prestasi belajar siswa pada siklus I adalah terjadi peningkatan rata-rata nilai prestasi belajar siswa sebesar 4,67; ketuntasan belajar sebesar $18,42 \%$ dan daya serap sebesar $4,67 \%$. Dengan demikian proses perbaikan pembelajaran yang dilakukan peneliti dapat terlaksana sesuai dengan tujuan perbaikan dan prestasi belajar siswa dapat meningkat 
melalui pengunaan media pembelajaran power point.

Peningkatan prestasi belajar siswa terjadi karena dengan media pembelajaran power point guru dapat menciptakan berbagai situasi baru dalam kelas, sehingga tidak membosankan. Selain itu juga, media pembelajaran power pont dapat membantu menciptakan iklim emosional yang sehat di antara siswa-siswanya dan membantu guru untuk "membawa" bahan pembelajaran ke dalam kelas dengan mudah melalui fasilita dan komponen yang terdapat pada power point tersebut sepertinya penyisipan video dan gambar, pemilihan font yang bervariasi, animasi dan lain-lain sehingga materi yang sifatnya abstrak dan asing dapat menjadi konkret dan mudah dimengerti oleh siswa.

Hal ini sejalan dengan penelitian yang dilakukan oleh Erna (2015); Elfira dan Ghufron (2015) dimana pembelajaran dengan menggunakan media power point dapat meningkatkan prestasi belajar. Kemudian, penelitian yang dilakukan oleh Utami (2018) mengatakan bahwa pelaksanaan pembelajaran dengan menggunakan media pembelajaran power point dapat meningkatkan kreaktivitas, keaktifan dan prestasi belajar siswa pada mata pelajaran aqidah akhlak pada kelas VIII I di MTsN Blitar.

\section{PENUTUP}

Berdasarkan pada uraian-uraian sebelumnya, akhirnya penulis dapat mengambil simpulan sebagai berikut (1) penggunaan power point siswa kelas XI IPS 1 Madrasah Aliyah Negeri 2 Banjarmasin pada awalnya adalah sulit. Setelah dilakukan bimbingan secara komprehensif akhirnya pada siklus kedua penggunaan power point dapat dilakukan secara baik dan lancar; (2) prestasi belajar siswa pada mata pelajaran aqidah akhlak materi akhlak terpuji dalam pergaulan remaja yang diperoleh siswa Kelas XI IPS 1 Madrasah Aliyah Negeri 2 Banjarmasin, sebelum diberikan tindakan terdapat $65,79 \%$ yang tuntas, kemudian pada siklus pertama mengalami peningkatan menjadi $71,05 \%$, selanjutnya pada siklus kedua menjadi $89,47 \%$ dan (3) prestasi belajar aqidah akhlak materi akhlak terpuji dalam pergaulan remaja yang diperoleh siswa Kelas XI IPS 1 Madrasah Aliyah Negeri 2 Banjarmasin dengan menggunakan power point mulai siklus I sampai dengan siklus II terus mengalami peningkatan yang cukup signifikan, yaitu dari kenaikan nilai rata-rata prestasi belajar siswa sebesar 78,18 kemudian mengalami peningkatan pada siklus II adalah sebesar 82,58. Sehingga terdapat peningkatan nilai prestasi belajar sebesar 4,4. Dengan demikian prestasi belajar siswa pada mata pelajaran aqidah akhlak materi akhlak terpuji dalam pergaulan remaja yang diperoleh siswa Kelas XI IPS 1 Madrasah Aliyah Negeri 2 Banjarmasin mengalami peningkatan yang cukup signifikan setelah digunakan power point.

Penggunaan power point diharapkan dapat dilaksanakan dengan sebaik-baiknya oleh siswa khususnya pada pelajaran aqidah akhlak materi akhlak terpuji dalam pergaulan remaja. Siswa diharapkan untuk terus meningkatkan belajarnya, sehingga diperoleh kualitas pembelajaran yang baik. Guru dan siswa diharapkan menggunakan power point dalam proses pembelajaran.

\section{DAFTAR PUSTAKA}

Arikunto, S., Suhardjono, \& Supardi. (2014). Penelitian Tindakan Kelas. Jakarta: Bumi Aksara.

Daryanto. (2013). Media Pembelajaran. Yogyakarta: Gava Media.

Dina, I. (2011). Ragam Alat Bantu Media Pengajaran. Yogyakarta: DIVA Press.

Elfira, N., \& Ghufron, A. (2015). Pengaruh penggunaan media powerpoint terhadap minat dan hasil belajar ipa siswa kelas IV SD. Jurnal Inovasi Teknologi Pendidikan, 2(1), 94-104. doi: 10.21831/tp.v2i1.5207.

Erna, K. (2015). Penggunaan media power point untuk untuk meningkatkan prestasi belajar mata pelajaran IPS di kelas VI SDN kaliasin VII surabaya. 
Jurnal Penelitian Pendidikan Guru Sekolah Dasar, 3(2), 163.

Robinson, D.N.A. (2008). Asas-Asas Praktik Mengajar, Penyadur: Suparno (et al), Jakarta: Bratara.

Rolina, F. A. (2017). Pengembangan media pembelajaran interaktif berbasis multimedia interaktif pada pokok bahasan peluang untuk siswa kelas XI. Jurnal Inovasi Pendidikan, 4(2), 180.

Saputra, H. G., \& Zinnurrain. (2018). Pengaruh penggunaan media ms powerpoint berbasis game terhadap hasil belajar siswa. Jurnal Teknologi Pendidikan, 3(1), 11-19.

Srimaya. (2017). Efektivitas media pembelajaran power point untuk meningkatkan motivasi dan hasil belajar biologi siswa. Jurnal Biotek, 5(1), 53-68.

Sutirman. (2013). Media \& Model-model Pembelajaran Inovatif. Yogyakarta: Graha Ilmu.

Suryandari, Kadarisman, N., \& Sudomo, J. (2018). Perbedaan keterampilan berpikir kritis siswa yang berbantuan media audio visual dan LKS cetak sebagai panduan percobaan pada metode eksperimen dengan pendekatan verifikasi kelas XI SMA negeri 1 sewon. Jurnal Tarbiyah: Jurnal Ilmiah Kependidikan, 7(1), 3740.

Utami, A. (2018). Penggunaan media pembelajaran power point dalam meningkatkan prestasi belajar siswa pada kelas VII pada mata pelajaran aqidah akhlak di MTSN blitar. Jurnal Pendidikan, 5(3), 120.

Widoyoko. (2014). Penilaian Hasil Pembelajaran di Sekolah. Yogyakarta: Pustaka Pelajar. 